\title{
Occurrence of Covid-19 in different communities in Kolkata
}

\author{
Jyotishman Mukhopadhyay ${ }^{1}$, Anant Chatterjee ${ }^{2}$, Debayan Mallik ${ }^{3}$, Chitra Chatterjee ${ }^{4}$ \\ ${ }^{1}$ Professor, ${ }^{2}$ Associate Professor, ${ }^{3}$ Assistant Professor, ${ }^{4}$ Professor and Head, Department of Community Medicine, \\ Jagannath Gupta Institute of Medical Science \& Hospital, Budge Budge, Kolkata-700137
}

Background: Scourge of ongoing COVID-19 pandemic is a matter of public health concern. New-norm preventive life-style like use of mask, repeated hand washing, social distancing and hygienic way of coughing-sneezing often compromise easy life and personal comfort. Earlier studies established certain epidemiological aspects of COVID-19 mostly in highend societies, but not many conducted on occurrence of COVID-19 in low-middle-income communities to ascertain the trend. Aims and Objective: Considering a possible upsurge of COVID-19 in Kolkata, it was decided to study the occurrence of COVID-19 in the background of preventive awareness and its application among residents in three different communities in Kolkata. Materials and Methods: Study was conducted in three different communities located in south Kolkata during Apr 20 to Mar 21. Community 1 and 2 were semi-urban clusters and Community 3, a high profile society; having 266, 282 \& 360 adults respectively. Consent was taken from authority as well as individual subjects. Questionnaire was made incorporating personal attributes, knowledge of personal protective measures (PPM) \& its application; lastly details of COVID-19 patients. Questionnaire was sent to willing members through e-mode; those declined were contacted individually following new-norm. Data collected was coded for confidentiality, tabulated and analysed. Confirmed COVID-19 (RT-PCR + ve) declared by Govt/private hospitals during Apr 20 to Mar 21 were included. Result: Communities studied had analogous demographic traits. Two communities belonged to low-SES group, while other enjoyed high-end-status. Almost $90 \%$ of slum/colony dwellers knew all facets of COVID-19 prevention compared to cent-percent of upper class people. $52 \%$ in one and around $93-100 \%$ in other two groups followed recommended PPM. Occurrence rates of COVID-19 infection were $11.3,10.6$ \& 11.1 per 1000 adult of respective communities during study period. Affected were mostly male $(90 \%)$ of $30-44$ year age with $60 \%$ from low SES \& $40 \%$ from the privileged. Many indisposed used masks (70\%), washed hands $(100 \%)$ and followed social distancing $(90 \%)$. Study unfurled the explicit distinctiveness of COVID-19 infection irrespective of social stand aside idealistic reflective of preventive awareness/application. PPM though renders protection but its circumventing role needs consistent application in back-lore of certain contextual considerations. Conclusion: Further research is recommended to enrich this endeavour to explore facts that may play vital role in COVID-19 prevention in future.

Key words: COVID-19; Social distancing; Physical contact greetings; Cough hygiene

\section{Access this article online}

Website:

http://nepjol.info/index.php/AJMS DOI: 10.3126/ajms.v12i7.36907

E-ISSN: 2091-0576

P-ISSN: 2467-9100

Copyright (c) 2021 Asian Journal of Medical Sciences

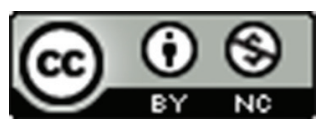

This work is licensed under a Creative Commons Attribution-NonCommercial 4.0 International License.

\section{INTRODUCTION}

COVID-19 pandemic seized the mankind to utter shock and escalated like a feral fire over the continents. Around 112 million were infected causing 2.48 million fatalities by mid Feb 21 worldwide amidst US leading with estimated
28.3 million cases and India recounted for 11 million infected. ${ }^{1}$ Conventional perception of COVID-19 infection emerged mainly from surveillance and epidemiological data accredited in the initial stage of the catastrophe in China, ${ }^{2,3}$ certain high-income European countries ${ }^{4,5}$ and North America. ${ }^{6-8}$ However, later in 2020, definite cases of 
COVID-19 developed in low and middle income countries (LMICs), where a large proportion of subjects continued to be at risk of critical consequences and often went through hardships in securing quality health care. ${ }^{9-11}$ Multiple studies in the past sought to establish certain epidemiological aspects of COVID-19 in community settings, ${ }^{12-14}$ but not many studies conducted on occurrence and dynamics of COVID-19 in LMIC communities to enlighten on intervention strategies. ${ }^{15}$ Kolkata is a densely inhabited city with sprawling trade and commerce, shops, markets and street vendors in the midst of stingy residential, commercial and settlement areas with warm sultry climate possibly provocative for strong epidemic challenges. Thinking through this milieu, it was decided to ascertain occurrence of confirmed COVID-19 cases in 3 different communities in Kolkata over a period of one year, inter-alia detect any associated factors related to such occurrence.

\section{MATERIALS AND METHODS}

The study was conducted in three different communities located in south Kolkata during the period Apr 20 to Mar 21. The first community (C1) studied, a settlement area for displaced persons with 102 built-up units within the premises housing 96 families having 380 members in total. The second community (C2) has been a slum in south Kolkata having 118 families with 402 members altogether, including 291 adults of whom only 282 subjects consented to participate. The third community (C3) comprised of 360 adults in a gated residential high-income society in south Kolkata having 104 families with 420 members. The communities were around 7-8 $\mathrm{km}$ apart from each other.

Approval was obtained from the concerned authorities for conduct of study. The members were contacted initially to explain the purpose of the study in Apr-May 20 and informed individual consent was obtained. Nominal roll of consenting members along with their address and mobile no. was prepared. A pertinent questionnaire was organized after reviewing existing literature incorporating required adjustments due local factors and issues.

The questionnaire contained three sections; first part had details of personal data besides socio-demographic traits with employment status of the subjects and second part included details of knowledge about personal protective measures (PPM) against COVID-19 along with preventive practices for the same. Third section accommodated details of COVID-19 acquisition, in case such emerged out. Socioeconomic status (SES) was determined as per recent scale. ${ }^{16}$

The questionnaire was introduced to all the willing members through mobile/electronic media; 106 members, who declined for mobile/e-interactions, were communicated individually in small groups at a time. Any doubt in data collected through e-mode was clarified during visit to the colony. Name, address and mobile no. of study subjects were coded ensuring confidentiality, but the record of the same was retained to avoid duplication protecting validity of data. Universal precautions like use of mask, hand sanitizer and social distancing were followed to avoid COVID-19 during the interactions. The data acquired was assimilated, tabulated and statistically validated to confer inference. Common statistical tests were applied to delineate significance of certain variables as appeared relevant.

Communities were kept under observation for occurrence of confirmed COVID-19 infection (RT-PCR +ve) as declared by the Government/private hospitals till Mar 21. Contacts were followed up in centres/home for possible development of the incriminating infection. Residents were reminded time and again the basic preventive measures to avert COVID-19.

\section{RESULTS}

Community $1 \& 2$ resided on the southern flank of a main road connecting Kolkata further down to south 24-parganas district of West Bengal around 7-8 km apart. Houses are generally brickwork with asbestos roof, while few of them are make-shift improvised type. Public toilets, municipal water supply point, water hand-pumps and street lights are on hand but not sufficient to make common life at ease. Open drainage system is unkempt with disorganized surroundings and irregular garbage disposal. Govt. hospital and dispensary facilities are available in walking distance from both the communities. Community 3 stayed in a gated society having well-maintained, multi-storied apartment complex with high profile members including many working ladies enjoying most of the facilities of modern living.

Community 1, 2 \& 3 housed 380, $402 \& 420$ members respectively with 949, 923 and 917 female per 1000 male correspondingly (Table-1). Working members (20-59 year) constituted $50.5 \%, 51.5 \%$ \& $62 \%$ of the group population sequentially. Under-19 children comprised of 14 to $30 \%$ of the total subjects under study; family size estimated to be $3.9,3.4 \& 4$ respectively.

Majority (36.5\%) in C-1 were educated up to primary standards as against preponderant proportion of subjects (34\%) of C-2 up to middle school and C3 had 64\% graduates (Table-2). 33.4 \& 30\% individuals from C1 \& C2 group were educated up to middle school and primary 
Table 1: Age \& sex of the respondents

\begin{tabular}{|c|c|c|c|c|c|c|c|c|c|}
\hline \multirow{2}{*}{$\begin{array}{l}\text { Age group } \\
\text { in years }\end{array}$} & \multicolumn{3}{|c|}{ Community 1} & \multicolumn{3}{|c|}{ Community 2} & \multicolumn{3}{|c|}{ Community 3} \\
\hline & Male & Female & No. (\%) & Male & Female & No. (\%) & Male & Female & No. (\%) \\
\hline $1-9$ & 22 & 26 & $48(12.6)$ & 25 & 31 & $56(13.9)$ & 17 & 13 & $30(7.1)$ \\
\hline $10-19$ & 37 & 29 & $66(17.4)$ & 26 & 29 & $55(13.7)$ & 14 & 16 & $30(7.1)$ \\
\hline $20-29$ & 50 & 44 & $94(24.7)$ & 56 & 45 & $101(25.1)$ & 70 & 56 & $126(30.0)$ \\
\hline $30-44$ & 50 & 48 & $98(25.8)$ & 56 & 50 & $106(26.4)$ & 68 & 66 & 134(31.9) \\
\hline $45-59$ & 31 & 29 & $60(15.8)$ & 36 & 32 & $68(16.9)$ & 46 & 44 & $90(21.4)$ \\
\hline $60+$ & 5 & 9 & 14(03.7) & 10 & 6 & $14(3.5)$ & 4 & 6 & $10(2.4)$ \\
\hline Total & $195(51.3)$ & $185(48.7)$ & $380(100.0)$ & $209(52.0)$ & $193(48.0)$ & 402 (100.0) & 219 (52.2) & $201(47.8)$ & $420(100.0)$ \\
\hline
\end{tabular}

Table 2: Educational status of adult respondents

\begin{tabular}{lccc}
\hline $\begin{array}{l}\text { Educational } \\
\text { Qualification }\end{array}$ & $\begin{array}{c}\text { Community 1 } \\
\text { Total (\%) }\end{array}$ & $\begin{array}{c}\text { Community 2 } \\
\text { Total (\%) }\end{array}$ & $\begin{array}{c}\text { Community 3 } \\
\text { Total (\%) }\end{array}$ \\
\hline Post Doctoral & - & - & $29(8.1)$ \\
Post-graduate & - & - & $79(21.9)$ \\
Graduate & $39(14.7)$ & $40(14.2)$ & $230(63.9)$ \\
Secondary & $41(15.4)$ & $56(19.9)$ & $22(6.1)$ \\
Middle School-VIII Std & $89(33.4)$ & $96(34.0)$ & -- \\
Primary & $97(36.5)$ & $85(30.1)$ & -- \\
Illiterate & - & $5(1.8)$ & -- \\
Total & $266(100.0)$ & $282(100.0)$ & $360(100.0)$ \\
\hline
\end{tabular}

\begin{tabular}{|c|c|c|c|c|c|c|c|c|c|}
\hline \multirow{2}{*}{$\begin{array}{l}\text { Socio-economic } \\
\text { status }\end{array}$} & \multicolumn{3}{|c|}{ Community 1} & \multicolumn{3}{|c|}{ Community 2} & \multicolumn{3}{|c|}{ Community 3} \\
\hline & Hindu & Muslim & No. (\%) & Hindu & Muslim & No. (\%) & Hindu & Muslim & No. (\%) \\
\hline Upper & -- & -- & -- & -- & -- & -- & 332 & 28 & $360(100.0)$ \\
\hline Upper middle & -- & -- & -- & -- & -- & -- & -- & -- & -- \\
\hline Middle & 27 & 7 & $34(12.8)$ & 34 & 5 & $39(13.8)$ & -- & -- & -- \\
\hline Lower middle & 90 & 17 & 107(40.2) & 99 & 14 & $113(40.1)$ & -- & -- & -- \\
\hline Total & 227 (85.3) & $39(14.7)$ & $266(100.0)$ & $246(87.2)$ & $36(12.8)$ & $282(100.0)$ & 332 (92.2) & $28(7.8)$ & $360(100.0)$ \\
\hline
\end{tabular}

standard correspondingly. Higher educational achievement in C3 is statistically significant.

Members of C3 group belonged to upper most class of SES scale as against majority (47\% \& 46.1\%) in C1 and C2 groups hailed from lower most SES scale as per recent SES classification respectively (Table-3). 85.3, 87.2 \& $92.2 \%$ of the members were Hindu in C1, C2 \& C3 groups as compared to $14.7,12.2 \& 7.8 \%$ were Muslim correspondingly.

Table- 4 represents that the awareness of the respondents on COVID-19 was quite high and almost $90 \%$ or more of the residents of all the 3 communities knew most of the basic facts of COVID-19 infection and its prevention with exception of few in $\mathrm{C} 1$ about importance of sanitizer $(88.4 \%)$ and risk in personal contact greetings $(85.7 \%)$. Every single member of C3 group was found strikingly clued-up and the finding is statistically significant.

Each member of Community 3 practiced most of the preventive measures in general except using gloves outdoor
(Table-5). Around 92\% members of Community $1 \& 2$ observed cough hygiene and avoided personal contact greetings. All the members from each of the communities maintained personal hygiene. However, around 52-55\% subjects practiced putting on mask, social distancing $\&$ hand washing in Community 1 as against $93-95 \%$ in Community 2 and cent-percent in Community 1. The differences are statistically significant.

There were $3,3 \& 4$ confirmed cases of COVID-19 among the members of Community $1,2 \& 3$ respectively amounting to an occurrence rate of $11.3,10.6 \& 11.1$ per 1000 adult population of the community members during the period of study (Table-6). $60 \%$ of the affected belonged 30-44 years age, majority (90\%) were male with (40\%) from high income/educated group. While $70 \%$ put on mask, cent-percent washed hands twice a day before meals and $90 \%$ followed social distancing, however only $40 \%$ used alcohol based sanitizer. $70 \%$ suspected to have contracted the disease at workplace and only $60 \%$ were admitted in hospital on diagnosis and all recovered uneventfully. $50 \%$ cases occurred in the month of Aug 20 


\begin{tabular}{|c|c|c|c|c|}
\hline Awareness indices & $\begin{array}{c}\text { Community } 1 \\
\text { Aware (No. \& \%) } \\
n^{1}-266\end{array}$ & $\begin{array}{c}\text { Community } 2 \\
\text { Aware (No. \& \%) } \\
n^{2}-282\end{array}$ & $\begin{array}{c}\text { Community } 3 \\
\text { Aware (No. \& \%) } \\
n^{3}-360\end{array}$ & $p$ value \\
\hline Became aware of COVID-19 in TV \& public advertisement & 250(93.9) & $264(93.6)$ & $360(100.00)$ & $\begin{array}{l}\text { Chi sq 23.2, } \\
p<0.05\end{array}$ \\
\hline COVID-19 transmits through cough \& sneezing & 248(93.2) & 265(93.9) & $360(100.00)$ & $\begin{array}{l}\text { Chi sq 24.1, } \\
\text { p<0.05 }\end{array}$ \\
\hline COVID-19 is highly infectious & 253(95.1) & $268(95.0)$ & $360(100.00)$ & $\begin{array}{l}\text { Chi sq 15.3, } \\
p<0.05\end{array}$ \\
\hline COVID-19 causes fatal outcome among elderly & $251(94.4)$ & 261(92.6) & $360(100.00)$ & $\begin{array}{l}\text { Chi sq 23.1, } \\
\quad p<0.05\end{array}$ \\
\hline Washing hand with soap \& water repeatedly prevents & 254(95.5) & 268(95.0) & $360(100.00)$ & $\begin{array}{l}\text { Chi sq } 15.1 \\
p<0.05\end{array}$ \\
\hline Wearing mask outdoor prevents COVID-19 & 250(93.9) & $266(94.3)$ & $360(100.00)$ & $\begin{array}{l}\text { Chi sq } 19.2 \text {, } \\
\quad p<0.05\end{array}$ \\
\hline Social distancing prevents COVID- 19 & 250(93.9) & 267(94.7) & $360(100.00)$ & $\begin{array}{l}\text { Chi sq } 18.6 \\
\quad p<0.05\end{array}$ \\
\hline Importance of daily bath \& good personal hygiene & 250(93.9) & $260(92.2)$ & $360(100.00)$ & $\begin{array}{l}\text { Chi sq 24.4 } \\
\quad p<0.05\end{array}$ \\
\hline Use of alcohol based sanitizer to disinfect hand helps & $235(88.4)$ & 265(93.9) & $360(100.00)$ & $\begin{array}{l}\text { Chi sq } 39.1 \text {, } \\
\quad p<0.05\end{array}$ \\
\hline Covering mouth/ nose in case of cough \& sneezes helps & 244(91.7) & 265(93.9) & $360(100.00)$ & $\begin{array}{l}\text { Chi sq 25.7, } \\
\quad p<0.05\end{array}$ \\
\hline Not shaking hand or hugging friends/ relatives prevents & $228(85.7)$ & 264(93.6) & $360(100.00)$ & $\begin{array}{l}\text { Chi sq } 51.0 \\
\quad p<0.05\end{array}$ \\
\hline $\begin{array}{l}\text { To report to nearest health centre in case of cough, cold, } \\
\text { fever, breathing difficulty \& loose motion }\end{array}$ & 254(95.5) & 266(94.3) & $360(100.00)$ & $\begin{array}{l}\text { Chi sq 17.0, } \\
\quad p<0.05\end{array}$ \\
\hline
\end{tabular}

\begin{tabular}{|c|c|c|c|c|}
\hline Safety measures & $\begin{array}{c}\text { Community } 1 \\
\left(n^{1}-266\right) \\
\text { No.(percent) }\end{array}$ & $\begin{array}{c}\text { Community } 2 \\
\left(n^{2}-282\right) \\
\text { No.(percent) }\end{array}$ & $\begin{array}{c}\text { Community } 3 \\
\left(n^{3}-360\right) \\
\text { No.(percent) }\end{array}$ & $p$ value \\
\hline Washing hand with soap/water twice, at least before meals & $147(55.3)$ & 265(93.9) & $360(100.0)$ & Chi sq 266.1, $p<0.05$ \\
\hline Washing hand with soap \& water 3 times or more everyday & $96(36.1)$ & 169(59.9) & $360(100.0)$ & Chi sq 306.3, $p<0.05$ \\
\hline Wearing mask while going out for daily need or work & $139(52.3)$ & 268(95.0) & $360(100.0)$ & Chi sq 296.6, $p<0.05$ \\
\hline $\begin{array}{l}\text { Social distancing from others in shops, markets \& public } \\
\text { places }\end{array}$ & $139(52.3)$ & 266(94.3) & $360(100.0)$ & Chi sq 290.1, $p<0.05$ \\
\hline Wearing gloves in market places \& shops & $16(6.0)$ & $46(16.3)$ & $292(64.4)$ & Chi sq 688.7, $p<0.05$ \\
\hline Taking daily bath \& maintaining personal hygiene & $266(100.00)$ & 282(100.0) & $360(100.0)$ & --- \\
\hline Not spitting in public places & $207(77.8)$ & $210(74.5)$ & $360(100.0)$ & Chi sq $98.8, p<0.05$ \\
\hline Using alcohol based sanitizer to disinfect hand & $106(39.8)$ & 192(68.1) & $360(100.0)$ & Chi sq 277.8, $p<0.05$ \\
\hline Covering mouth \& nose in case of cough \& sneezes & $245(92.1)$ & 262(92.9) & $360(100.0)$ & Chi sq 25.8, $p<0.05$ \\
\hline Not shaking hand or hugging anyone & $247(92.9)$ & $258(91.5)$ & $360(100.0)$ & Chi sq $25.5, p<0.05$ \\
\hline
\end{tabular}

and certain no. of contacts (22) of the sick was quarantined at home.

\section{DISCUSSION}

The communities studied depicted the demographic features including age- sex composition, gender ratio and family size not only comparable among the groups but even analogous to national statistics. ${ }^{17}$ Working elements belonging to 20-59 year age group represented 50.5\%, $51.5 \%$ \& $62 \%$ of the group population correspondingly of which women contribution in family coterie stood for $17.6 \%, 18.2 \%$ \& $19 \%$ respectively. Cent-percent subjects of Community $1 \& 3$ beside $98 \%$ in Community 2 were literate; the literacy rate in West Bengal has been documented as $77.08 \%{ }^{18}$ However the C3 assemblages enlivened the upper most class of SES in contrast to majority (47 \& 46.1\% respectively) in C1 and C2 groups appertaining to lower most SES scale. Essential literacy, small family and dual income in C1 \& C2 groups depicted the sign of trying human development and enrichment of Kolkata slum in the face of financial hardship even though the civic facilities might not have been up to the mark.

Understanding of the respondents on prevention and preclusion of COVID-19 was reasonably good and almost $90 \%$ or more of the subjects from C1 \& C2 knew most of the basic facts of COVID-19 infection. Members of C3 group were expedient to be remarkably au-fait about the preventive measures against COVID-19. Present study 


\begin{tabular}{|c|c|c|c|c|}
\hline Attributes & Community 1 & Community 2 & Community 3 & Total (\%) \\
\hline No. of subjects affected & 3 & 3 & 4 & 10 \\
\hline \multicolumn{5}{|l|}{ Age group } \\
\hline $30-44$ & 2 & 1 & 3 & $6(60.0)$ \\
\hline $45-59$ & 1 & 2 & 1 & $4(40.0)$ \\
\hline \multicolumn{5}{|l|}{ Gender } \\
\hline Male & 3 & 3 & 3 & $9(90.0)$ \\
\hline Female & - & - & 1 & $1(10.0)$ \\
\hline \multicolumn{5}{|l|}{ SES } \\
\hline Upper & 1 & 2 & 4 & $4(40.0)$ \\
\hline Lower middle & 2 & 1 & - & $3(30.0)$ \\
\hline Lower & & & - & $3(30.0)$ \\
\hline \multicolumn{5}{|l|}{ Education } \\
\hline Post Graduate & - & - & 3 & $3(30.0)$ \\
\hline Graduate & - & - & 1 & $1(10.0)$ \\
\hline Middle school & 2 & 2 & - & $4(40.0)$ \\
\hline Primary & 1 & 1 & - & $2(20.0)$ \\
\hline \multicolumn{5}{|l|}{ Preventive Practices \& others } \\
\hline Worn Mask & 2 & 1 & 4 & $7(70.0)$ \\
\hline Washed hands before meals & 3 & 3 & 4 & $10(100.0)$ \\
\hline Social distancing & 3 & 2 & 4 & $9(90.0)$ \\
\hline Contact greetings & - & - & - & - \\
\hline Used sanitizer & - & - & 4 & $4(40.0)$ \\
\hline \multicolumn{5}{|l|}{ Suspected place of acquisition } \\
\hline Work place & 2 & 3 & 2 & $7(70.0)$ \\
\hline Market & 1 & - & 1 & $2(20.0)$ \\
\hline Others & - & - & 1 & $1(10.0)$ \\
\hline Admitted to hospital & 1 & 1 & 4 & $6(60.0)$ \\
\hline \multicolumn{5}{|l|}{ Month of acquisition } \\
\hline Aug 20 & 2 & 2 & 1 & $5(50.0)$ \\
\hline Sep 20 & 1 & 1 & 2 & $4(40.0)$ \\
\hline Dec 20 & - & - & 1 & $1(10.0)$ \\
\hline \multicolumn{5}{|l|}{ Quarantine of contacts } \\
\hline Home & 7 contacts of 3 patients & 6 contacts of 3 patients & 9 contacts of 4 patients & $22(100.0)$ \\
\hline Center & - & - & - & - \\
\hline
\end{tabular}

revealed that $93 \%$ or more from each of the communities were up-to-date on transmissibility, infectivity and criticality of elderly persons infected with COVID-19. An earlier Indian study noted that $87.3 \%$ subjects were acquainted with the contagiousness, $57.1 \%$ knew the incubation period and cent-percent were familiar with symptoms of COVID-19. ${ }^{19}$ In the present intent, $93-100 \%$ subjects of the group population were resplendent of the importance of repeated hand washing, value of wearing mask, worth of social distancing aside daily bathing and upkeep of personal hygiene. Nevertheless, only $86-92 \%$ in C1 and $94 \%$ in C2 as compared to cent-percent respondents in C3 assemblage recognized the significance of avoidance of personal contact greetings, utility of hand sanitizer and observance of cough hygiene. It has been annotated earlier that washing hands and use of alcohol-based sanitizer $(23.3 \%)$, hygienic way of coughing/sneezing along with use of mask (19.6\%), social distancing (16.1\%) and following all preventative measures collectively $(40.2 \%)$ can ward off COVID-19. ${ }^{19}$ Indian authors documented that around $95-98 \%$ of the educated subjects had correct preventive knowledge to avert COVID-19 like frequent hand washing, social distancing, quarantine and isolation. ${ }^{20}$
Each member of C3 followed all the preventive measures in general except using gloves outdoor. Around 92\% members of C2 \& C3 observed cough hygiene and avoided personal contact greetings. Daily bathing and changing to fresh clothes were universal for all irrespective of the groups. However, around $52-55 \%$ subjects practiced hand washing, putting on mask and social distancing in C1 as against $93-95 \%$ in C2 and cent-percent in C1. It appears inopportune that even tall index of protective awareness couldn't ingeminate good preventive practices among members of C1 group. In India with approximately $80 \%$ people employed in informal sectors, implementation of personal hygiene and public health behaviours such as hand-washing, use of sanitizer and social distancing to curb COVID-19 will be exigent no doubt. ${ }^{21}$ However, recent work acknowledged that large no. of subjects practiced adequate preventive measures while outdoor like wearing masks (97.2\%), social distancing (95.3\%) and hand hygiene $(91.2 \%)$ that commensurate with findings in C2 \&C3 group. ${ }^{20}$ This has been largely possible due to stringent government initiatives to stall the plagued ripple of COVID-19 infection, also because of awareness, acceptance and action of people with compelling drive. ${ }^{22}$ 
The occurrence rates of COVID-19 were 11.3, 10.6 \& 11.1 per 1000 adult population of the community members during the period of study. Considering no. of COVID-19 infection as 5.87 lac in West Bengal and 12.2 million in India as on 31 Mar 21, the occurrence rates amount to $5.87 \& 8.77$ per 1000 population in West Bengal \& India respectively. ${ }^{23,24}$ Occurrence in present study is comparatively higher in contrast to state/national statistics and could be attributable to factors like under-reporting, missing data due to $\mathrm{CO}^{-}$ morbidity \& diagnostic fallacies in rural/far-flung areas in the backdrop of outsized state $\&$ national population.

Majority afflicted with COVID-19 were male (90\%), belonged to 30-44 year age group with $60 \%$ from low SES group. Preventive practices to avert COVID-19 were found significantly associated with the gender where females noticed to have been more stringent followers compared to males. ${ }^{25} \mathrm{~A}$ recent study from the Chennai stated that low-SES population encountered higher incidence of COVID-19 infections, suggesting that COVID-19 may unduly affect low-income individuals. ${ }^{26}$ Large proportion of indisposed persons used mask $(70 \%)$, washed hands twice a day $(100 \%)$ and followed social distancing (90\%). Surprisingly 40\% of the affected ones were from high SES group and dedicatedly followed all the precautionary measures. Although these measures afford prime protection from COVID-19 infection but their optimum role needs consistent application in the background of contextual considerations like physical discomfort, unclear communication and shortness of breath. ${ }^{27}$ Gratifyingly, all the patients recovered effectively and none among the quarantined developed the infection.

The study unveiled the unequivocal uniqueness COVID-19 acquisition irrespective of social status, towering index of preventive awareness and its application. Such disposition reflects indomitability of COVID-19 and therefore directs necessity for further research. The occurrence rates of COVID-19 infection among the studied groups are alike; however, higher than the state/national figures for explicable reasons.

This has been a limited endeavour among the residents of 3 different communities in south Kolkata for a particular time period of one year during peak corona season with restricted mobility in general; therefore the result needs guarded consideration for universal comparison. However, the information generated, envisages that continuous and consistent use of personal protective measures could be the key-most factor in averting the COVID-19. Further studies in similar directions may help to formulate future strategies to stall the burnt along with vaccination.

\section{ACKNOWLEDGEMENT}

The authors would to thank all members of Department of Community Medicine for their whole hearted support and dedication for this study.

\section{REFERENCES}

1. COVID-19 Alert: https://g.co/kgs/hZNqPc (seen on 25 Feb 21)

2. Qun Li, Guan X, Peng Wu, Wang X, Lei Zhou, Tong Y, et al. Early Transmission Dynamics in Wuhan, China of Novel CoronavirusInfected Pneumonia. N Engl J Med. 2020; 382:1199-1207. https://doi.org/10.1056/NEJMoa2001316

3. Zhou F, Yu T, Du R, Fa G, Liu Y, Liu Z, et al. Clinical course and risk factors for mortality of adult in-patients with COVID-19 in Wuhan, China: a retrospective cohort study. The Lancet. 2020; 395(10229): 1054-1062. https://doi.org/10.1016/S0140-6736(20)30566-3

4. Guan WJ, Ni ZY, Hu Y, Liang WH, Ou CQ, He JX, et al. Clinical Characteristics of Coronavirus Disease 2019 in China. N Engl J Med. 2020; 382:1708-1720.

https://doi.org/10.1056/NEJMoa2002032

5. Grasselli G, ZangrilloA, Zanella A, Antonelli M, Cabrini L, Castelli A, et al. Baseline Characteristics and Outcomes of 1591 Patients Infected with SARS-CoV-2. JAMA. 2020; 323(16):1574-1581. https://doi.org/10.1001/jama.2020.5394

6. Docherty AB, Harrison EM, Green CA, Hardwick HE, Pius R, Norman L,et al. Features of 20,133 UK patients in hospital with covid-19 using the ISARIC WHO Clinical Characterization Protocol: prospective observational cohort study. BMJ 2020; 369. https://doi.org/10.1136/bmj.m1985

7. Richardson S, Hirsch JS, Narasimhan M, Crawford JM, McGinn T, Davidson KW, et al. Presenting Characteristics, Comorbidities and Outcomes among 5700 Patients Hospitalized with COVID-19 in the New York City area. JAMA. 2020; 323(20):2052-2059.

https://doi.org/10.1001/jama.2020.6775

8. Petrilli CM, Jones SA, Yang J, Rajagopalan H, O’Donnell L, Chernyak $Y$, et al. Factors associated with hospital admission and critical illness among 5279 people with corona virus disease 2019 in New York City: Prospective cohort study. BMJ. 2020; 369.

https://doi.org/10.1136/bmj.m1966

9. Lewnard JA, Liu VX, Jackson ML, Schmidt MA, Jewell BL, Flores JP, et al. Incidence, clinical outcomes and transmission dynamics of severe corona virus disease 2019 in California and Washington: Prospective cohort study. BMJ. 2020; 369: m1923. https://doi.org/10.1136/bmj.m1923

10. Gardner L, Ratcliff J, Dong E and Katz A. A need for open public data standards and sharing in light of COVID-19. Lancet Infectious Disease. 2020; 20: 533-534. https://doi.org/10.1016/S1473-3099(20)30635-6

11. Clark A, Jit M, Warren-Gash C, Guthrie PB, Wang HHX, Mercer SW, et al. Global, regional and national estimates of the population at increased risk of severe COVID-19 due to underlying health conditions in 2020: A modeling study. The Lancet - Global Health. 2020; 8(8): e1003-e1017.

12. Coronavirus disease (COVID-19) situation report 209. (World Health Organization, 16 Aug 2020); www.who.int/docs/defaultsource/coronaviruse/situation-reports/20200816. covid-19sitrep-209.pdf/sfvrsn=5dde1ca2_2. 
13. Walker PGT, Whittaker C, Watson OJ, Baguelin M, Winskill P, Hamlet A, et al. The impact of COVID-19 and strategies for mitigation and suppression in low and middle-income countries. Science. 2020; 369 (6502): 413-422.

https://doi.org/10.1126/science.abc0035

14. Gilbert M, Pullano G, Pinotti F, Valdano E, Poletto C and PierreYves B. Preparedness and vulnerability of African countries against importations of COVID-19: a modelling study. The Lancet. 2020; 395 (10227): 871-877.

https://doi.org/10.1016/S0140-6736(20)30411-6

15. Davies NG, Klepac P, Liu Y, Prem K, Jit M, Eggo RM, et al. Age-dependent effects in transmission and control of COVID-19 epidemics. Nature Medicine. 2020; 26: 1205-1211. https://doi.org/10.1038/s41591-020-0962-9

16. Pandey VK, Aggarwal $P$ and Kakkar R. Modified BG Prasad's Socio-economic Classification - 2018: The need of an update in the present scenario. Indian Journal of Community Health. 2018; 30(1): 82-84.

17. Govt of India (2012), Sample Registration system Statistical Report 2010. Office of the Registrar General and Census Commissioner India. Min. of Home Affairs. New Delhi.

18. Govt of India (2012), Census 2011, Provisional Population Report. Office of the Registrar General and Census Commissioner India. Ministry of Home Affairs. New Delhi. 2011

19. Pandey S, Gupta A. Bhansali R, Balhara S, Katira P and Fernandes G. Corona Virus (COVID-19) Awareness Assessment - A Survey Study Amongst the Indian Population. J Clin Med Res. 2020; 2(4):1-10.

20. Shukla $S$ and Deotale P. Knowledge, attitude and practices towards COVID-19 pandemic in the community: a crosssectional web-based survey in India. International $\mathrm{J}$ of Res in
Med Sciences. 2020; 8 (10): 3652-3656.

https://doi.org/10.18203/2320-6012.jirms20204246

21. Acharya R, Gundi M, Thoai DN, Pandey N, Patel SK and Pinchoff J. COVID-19-related knowledge, attitudes and practices among adolescents and young people in Bihar and Uttar Pradesh, Apr 20. Report of Population Council of India, New Delhi. www.popcouncil.com accessed on 02 Apr 21

22. Tomar BS, Singh $P$, Suman $S$, Raj $P$ and Nathiya D. Indian community's knowledge, attitude and practice towards COVID-19. MedRxiv. 2020; 1-20.

https://doi.org/10.1097/01.NT.0000666928.05972.6b

23. COVID-19 cases in West Bengal. www.coronaclusters.in/westbengal/accessed on $02 \mathrm{Apr} 21$

24. COVID-19 cases in India. www.google.com/search/ kgmid $=/ \mathrm{g} / 11 \mathrm{j} 2 \mathrm{ccq} \|$ and $\mathrm{hl}=\mathrm{en}-\mathrm{IN}$ and $\mathrm{q}=$ Coronavirus and $\mathrm{kgs}=2 \mathrm{~d} 1 \mathrm{e} 110 \mathrm{bd} 7563 \mathrm{~d} 25$ and shndl=0 and source $=\mathrm{sh} / \mathrm{x} / \mathrm{kp} / \mathrm{osrp}$ and entrypoint=sh/x/kp/osrp accessed on $02 \mathrm{Apr} 21$.

25. Tegegne KT, Assefa1 AA, Tegegne ET and Tessema MK. Implication of gender on Covid- 19 prevention practice among adults in Ethiopia: A systemic review and meta-analysis. Res and Rev Health Care OAJ. 2020; 6(1): 562-566.

26. Das A, Ghosh S, Das K, Basu T, Das M and Dutta I. Modeling the effect of area deprivation on COVID-19 incidences: A study of Chennai megacity, India. Public Health. 2020; 185: 266-269. https://doi.org/10.1016/j.puhe.2020.06.011

27. Chu DK, Aki EA, Duda S, Solo K, Yaacoub S and Schünemann HJ. Physical distancing, face masks and eye protection to prevent person-to-person transmission of SARS-CoV-2 and COVID-19: a systematic review and meta-analysis. The Lancet. 2020; 395(10242): 1973-1987.

https://doi.org/10.1016/S0140-6736(20)31142-9

\section{Authors contribution:}

JM- Concept and design of the study; prepared first draft of manuscript; AC-Interpreted the results; reviewed the literature and manuscript preparation;

DM- Concept, coordination, review of literature and manuscript preparation; CC- Statistically analysed and interpreted, preparation of manuscript and revision of the manuscript.

Work affiliation:

Department of Community Medicine, Jagannath Gupta Institute of Medical Science \& Hospital, Budge-Budge Kolkata - 700137

Orcid ID:

Dr. Anant Chatterjee- (iD https://orcid org/0000-0003-2624-2799

Dr. Debayan Mallik- (D https://orcid.org/0000-0002-1429-5896

Dr. Chitra Chatterjee- (1) https://orcid.org/0000-0003-1898-634

Source of Funding: None, Conflict of Interest: None. 